\title{
Development and test of a remotely operated Minisampler for discrete trawl sampling
}

\author{
Madsen, Niels; Hansen, Kurt E.; Frandsen, Rikke; Krag, Ludvig Ahm
}

Publication date:

2010

Document Version

Publisher's PDF, also known as Version of record

Link back to DTU Orbit

Citation (APA):

Madsen, N., Hansen, K. E., Frandsen, R., \& Krag, L. A. (2010). Development and test of a remotely operated Minisampler for discrete trawl sampling. Poster session presented at Fsam 2010 : Fish Sampling with Active Methods, September 8-11, Ceske Budejovice, Czech Republic.

\section{General rights}

Copyright and moral rights for the publications made accessible in the public portal are retained by the authors and/or other copyright owners and it is a condition of accessing publications that users recognise and abide by the legal requirements associated with these rights.

- Users may download and print one copy of any publication from the public portal for the purpose of private study or research.

- You may not further distribute the material or use it for any profit-making activity or commercial gain

- You may freely distribute the URL identifying the publication in the public portal 


\title{
Development and test of a remotely operated Minisampler for discrete trawl sampling
}

\author{
Niels Madsenª, Kurt E. Hansen ${ }^{b}$, Rikke Petri Frandsen, Ludvig Ahm Kraga \\ aDTU Aqua, National Institute of Aquatic Resources, North Sea Science Park, DK-9850 Hirtshals, Denmark \\ bSINTEF Fisheries and Aquaculture, North Sea Science Park DK-9850 Hirtshals, Denmark \\ *Corresponding author. Tel.: +45-3396-3200; E-mail address: nm@aqua.dtu.dk (Niels Madsen)
}

Systems that can take discrete samples of a trawl catch are widely used. We developed the Minisampler, which is a relatively small system that particularly is made to be used on small vessels and small trawls. The device is simple, have a low weight and can be made at a reasonable cost. The Minisampler consists of a telecommand deck unit, a dunking transducer, a stainless steel frame and one or two acoustical trigger-units that release a metal bar that opens a collecting bag. It is possible to take two or three remotely controlled discrete samples during a tow. We tested the system successfully in a flume tank and during sea trials from a commercial trawler. The Minisampler can be used for multiple purposes and provides the opportunity for new experimental designs to improve scientific work.

We have constructed two Minisampler devices: a dual-sampler and a triple-sampler (Figs. 1 and 2). The dual sampler consists of a frame with an attached collecting bag that can be released by an acoustic release unit triggered from a deck unit on a vessel. The triple sampler has two collecting bags that can be released from two different acoustic release units. The stainless steel frame of the dual sampler weighs $\sim 10 \mathrm{~kg}$ in air and the triple sampler $\sim 16 \mathrm{~kg}$. The main difference in the dual sampler and the triple sampler is the height. The dual-sampler is $92 \mathrm{~cm}$ in height and the triple sampler is $127 \mathrm{~cm}$. The frame of the triple-sampler is shown in Fig. 1.

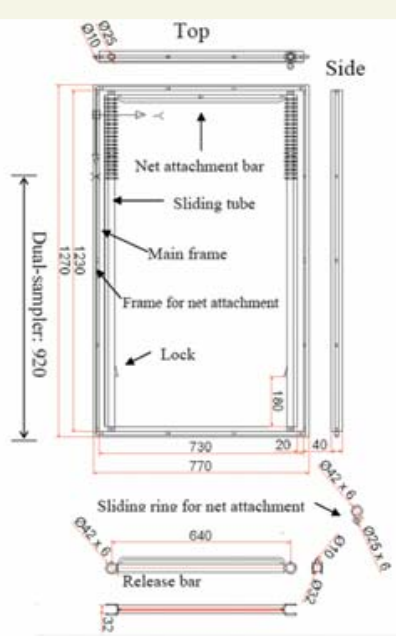

Fig. 1. Drawing of the triple sampler frame. The height of the dual sampler is indicated.
Acoustic releasers are attached to the upper panel of the net in front of the frame. The acoustic releasers are released from a from a deck unit consisting of a tele-command unit and a dunking transducer. A rope connected to the release bar is released and two kites and a $2 \mathrm{~kg}$ weight on the release bar open the collection bag and simultaneously prevent access to former collecting bag (Fig. 2).

The Minisamplers have been tested Hirtshals flume tank (Denmark) (Fig 3.). We have also used the system during demersal trawl selectivity experiments using a relatively small $(20 \mathrm{~m})$ commercial fishing vessel which had no ramp. Two dualsamplers were placed on codend covers (Fig. 2), made to collect escaping fish from the trawl codends (Madsen et al., 2001) that were fished simultaneously in a twin-trawl system.

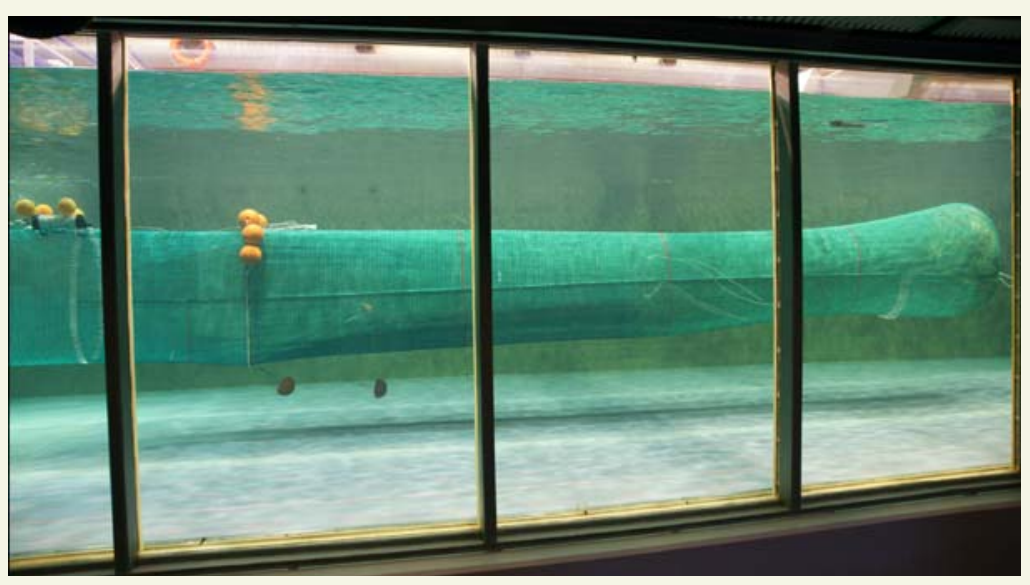

Figure 3. The triple-sampler in the Hirtshals (Denmark) flume tank.
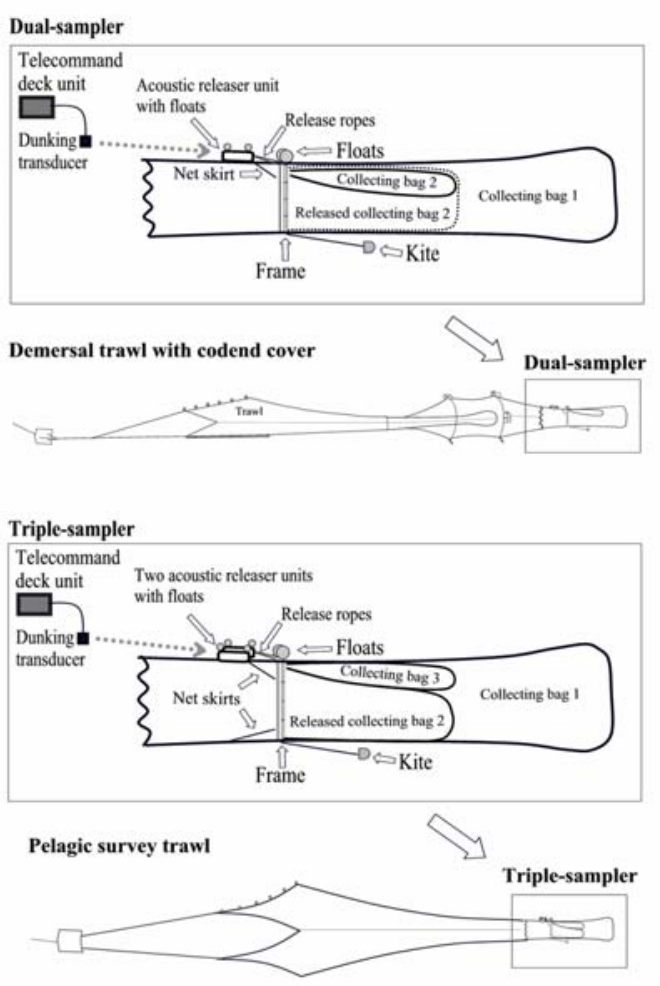

Figure 2. The dual-sampler and triple-sampler and examples on use.

Our system is not as advanced as the widely used MultiSampler system (Engås et al., 1997). The advantage is that it weighs considerably less (< 10\%) and consequently, it is easier to handle on land and on the vessel, and it can be used from small vessels, including commercial vessels where working space is limited. In addition the price is modest (to our knowledge, $<10 \%$ of the cost of a MultiSampler system) and the system is simple to operate opening wider perspectives for use as a standard device for various monitoring tasks.

Reference: Engås, A., Skeide, R., and West, C.W., 1997. The "MultiSampler": a system for referetely opening and closing multiple codends on a sampling trawl. Fish. Res. 29, 295-
298 . 